\title{
Jean-Bernard Vray, François Bon, chiffonnier de la mémoire collective dans 'Paysage fer'
}

\section{Rosa Galli Pellegrini}

\section{(2) OpenEdition}

1 Journals

\section{Edizione digitale}

URL: http://journals.openedition.org/studifrancesi/33713

DOI: 10.4000/studifrancesi.33713

ISSN: 2421-5856

\section{Editore}

Rosenberg \& Sellier

\section{Edizione cartacea}

Data di pubblicazione: 1 décembre 2005

Paginazione: 679-680

ISSN: 0039-2944

\section{Notizia bibliografica digitale}

Rosa Galli Pellegrini, «Jean-Bernard Vray, François Bon, chiffonnier de la mémoire collective dans 'Paysage fer'», Studi Francesi [Online], 147 (XLX | III) | 2005, online dal 30 novembre 2015, consultato il 18 avril 2021. URL: http://journals.openedition.org/studifrancesi/33713 ; DOI: https:// doi.org/10.4000/studifrancesi.33713

\section{Questo documento è stato generato automaticamente il 18 avril 2021.}

\section{(c)}

Studi Francesi è distribuita con Licenza Creative Commons Attribuzione - Non commerciale - Non opere derivate 4.0 Internazionale. 


\section{Jean-Bernard Vray, François Bon, chiffonnier de la mémoire collective dans 'Paysage fer'}

Rosa Galli Pellegrini 


\section{NOTIZIA}

JEAN-BERNARD VRAY, François Bon, chiffonnier de la mémoire collective dans 'Paysage fer', in La Mémoire des villes, sous la direction de Yves Clavaron et Bernard Dieterle, Publications de l'Université de Saint-Étienne, 2003, pp. 107-122.

1 François Bon è uno scrittore contemporaneo sul quale la critica sta focalizzando sempre di più l'attenzione. L'A. contribuisce a farlo conoscere meglio. Autore di romanzi, di récits, di scritti che vanno al di là della tradizionale definizione dei generi, Bon ha ormai a suo attivo decine di testi. Uno degli elementi ricorrenti nella sua scrittura è la descrizione o l'utilizzo lirico del paesaggio urbano. Lo studioso, affronta in questo articolo la lettura di un testo, Paysage fer (Verdier, 2000), scritto nei due anni che viaggiò in ferrovia per raggiungere Nancy, dove dirigeva un "atelier d'écriture". Dopo aver passato in rassegna testi precedenti nei quali Bon si confronta con il paesaggio urbano, l'A. passa alla lettura di Paysage fer in una visione tripartita, di cui il primo pannello si addentra nella modalità della percezione del paesaggio, in realtà suburbano, da parte dello scrittore/viaggiatore, personaggio particolarmente esperto nel reperire le tracce tecniche del lavoro dell'uomo ( Bon è stato a lungo in fabbrica). L'approccio successivo colloca il testo in un rapporto con le tracce della memoria e con l'attività svolta dallo scrittore nel raccogliere la voce (in questo caso le vestigia) di chi (o di ciò che) non riesce ad esprimersi. L'ultima considerazione del critico porta il testo ad essere visto come un deposito della memoria collettiva di materiali desueti, e l'autore stesso come lo "chiffonier", appunto, il robivecchi della storia. 